\title{
KARAKTERISTIK FISIKOKIMIA SENYAWA KUERSETIN BERTANDA RADIOAKTIF IODIUM-131
}

\section{PHYSICOCHEMICAL CHARACTERISTICS OF QUERCETIN LABELED IODINE-131}

\author{
A. Maula Eka Sriyani', B. Eva Maria Widyasari', C. Hesti Febriyanti², D. Rizky Juwita Sugiharti', \\ E. lim Halimah', F. Isti Daruwati ${ }^{1}$ dan G. Aang Hanafiah W. ${ }^{2}$ \\ 1)PSTNT BATAN, Jl. Tamansari No. 71, Bandung, 40132. \\ 2) STFI, Jl. Soekarno Hatta No 354 (Parakan Resik 1), Bandung \\ Email : maula@batan.go.id
}

Diterima 25 Juli 2019, diterima dalam bentuk perbaikan 27 Desember 2019, disetujui 5 April2020

\begin{abstract}
ABSTRAK
KARAKTERISTIK FISIKOKIMIA SENYAWA KUERSETIN BERTANDA RADIOAKTIF IODIUM-131. Penggunaan bahan-bahan herbal (obat tradisional) untuk pengobatan penyakit-penyakit kronis semakin banyak dikonsumsi. Fenomena ini mendorong perkembangan penelitian dan penemuan obat baru berbasis bahan alam melalui proses isolasi maupun sintesis. Salah satu tahapan pengembangan obat dalam penentuan efikasi adalah pemanfaatan teknologi nuklir pada tahap uji preklinis baik secara in-vitro maupun in-vivo. Pada tahap awal penelitian, telah dilakukan pemilihan bahan aktif berkhasiat antikanker dan penelaahan kemungkinan senyawa tersebut untuk ditandai menggunakan radioisotop pemancar beta ( $\beta$-). Penelaahan meliputi struktur kimia bahan aktif tersebut (kemungkinan ikatan yang mungkin terjadi antara senyawa aktif dengan radioisotop pemancar beta), serta teknik penandaan yang akan dilakukan. Metode penandaan Kuersetin dengan radioisotop iodium-131 menggunakan oksidator Kloramin-T mengacu pada penelitian yang telah dilakukan oleh Barolli, dkk dengan sedikit modifikasi. Tujuan penelitian ini adalah untuk menentukan sifat fisikokimia senyawa bertanda ${ }^{131}$-kuersetin meliputi kemurnian radiokimia, muatan listrik senyawa ${ }^{131}$ Kuersetin, lipofilisitas (log P), ikatan dengan protein plasma dan stabilitas sediaan. Hasil yang didapat adalah senyawa ${ }^{131}$-Kuersetin dengan kemurnian radiokimia sebesar $98,41 \pm 1,05 \%$, memiliki muatan listrik negatif dan nilai koefisien partisi (log P) sebesar -2,22 di dalam Larutan NaCl dan -2,71 di dalam larutan dapar fosfat.

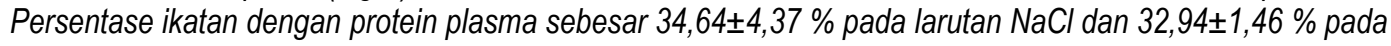
larutan dapar fosfat. Hasil pengujian variasi volume sediaan ${ }^{131}$-kuersetin, volume diatas $1 \mathrm{~mL}$ akan menurunkan kemurnian radiokimianya menjadi $<90 \%$. Sedangkan dari pengujian stabilitas sediaan ${ }^{131 /-}$ kuersetin tetap stabil hingga jam ke-72, pada suhu kamar dengan hasil kemurnian radiokimia yang tinggi $\geq$ $95 \%$.
\end{abstract}

Kata kunci: Antikanker, radioisotop, karakterisasi, Kuersetin, lodium-131

\section{ABSTRACT}

PHYSICOCHEMICAL CHARACTERISTICS OF QUERCETIN LABELED IODINE-131. The use of herbal ingredients (medicines) for the treatment of chronic diseases is increasingly consumed. This phenomenon encourages the development of research and discovery of new drugs based on natural materials through the process of isolation and synthesis. One of the phases of drug development in the determination of efficacy is the utilization of nuclear technology at the preclinical test stage, both in-vitro and in-vivo. In the first step of reseach, the study was conducted in the selection of anticancer active ingredients and the possibility of such compounds to be labeled using beta emitter radioisotopes $(\beta)$ and the labeling technique to be performed. Quercetin labeling method with radioisotope iodine-131 using chloramine-T oxidating agent was refers to a research done by Barolli et al with slight modification. The objective of this study was to determine the physicochemical properties of ${ }^{131} 1$-quercetin labeled compound including radiochemical purity, electric charge of 131 -quercetin, lipophilicity (log P), plasma protein binding and stability of ${ }^{131}$ I-quercetin. The result was 131/quercetin has radiochemical purity of $98.41 \pm 1.05 \%$, negative electric charge and the liphophylic value (log $P$ ) -2.22 in $\mathrm{NaCl}$ solution and -2.71 in phosphate buffer solution. The plasma protein binding percentages in $\mathrm{NaCl}$ solution and phosphate buffer solution was $34.64 \pm 4.37 \%$ and $32.94 \pm 1.46 \%$ respectively. The volume above 
$1 \mathrm{~mL}$ of ${ }^{131}$-quercetin decreased the radiochemical purity to $<90 \%$. ${ }^{131}$-quercetin remained stable until 72 hours, at room temperature with high radiochemical purity yield $\geq 95 \%$.

Keywords: Anticancer, radioisotope, characterization, quercetin, iodine-131

\section{PENDAHULUAN}

$\mathrm{K}_{\mathrm{b} \text { a }}^{\mathrm{an}}$ anker adalah suatu penyakit penyakit yang timbul akibat pertumbuhan tidak normal sel jaringan tubuh yang berubah menjadi sel kanker [1]. Kanker merupakan penyebab kematian nomor 2 di dunia setelah penyakit kardiovaskular. Menurut data WHO tahun 2013, terjadi peningkatan insiden kanker, dari semula sebanyak 2,7 juta kasus di tahun 2008, menjadi 14,1 juta kasus di tahun 2012. Pada tahun 2030, insiden kanker diperkirakan akan mencapai 26 juta kasus [3]. Di Indonesia, prevalensi kanker adalah sebesar 1,4 per 1.000 penduduk, serta merupakan penyebab kematian nomor $7(5,7 \%)$ dari seluruh penyebab kematian [3]. Presentase kasus baru dan kematian akibat kanker hati, kanker perut, dan kanker paru memiliki presentase yang hampir sebanding [4]. Data di atas menunjukkan bahwa insiden kanker cukup tinggi, oleh karena itu diperlukan penanggulangan kanker yang tepat. Pengobatan kanker dengan kemoterapi masih memiliki kelemahan karena selain membunuh sel kanker teknik tersebut juga mempengaruhi sel-sel normal dengan tingkat proliferasi cepat, seperti folikel rambut, sumsum tulang dan sel-sel saluran pencernaan, menghasilkan efek samping kemoterapi yang khas [5]. Deteksi dini dapat menurunkan angka penyakit kanker "stadium lanjut" sehingga angka kesembuhan penyakit kanker menjadi meningkat [6]. Kanker pada stadium awal termasuk kondisi pra-kanker yang dapat diobati dengan tingkat kesembuhan mendekati 100\% [7].

Salah satu metode alternatif untuk deteksi penyakit kanker adalah teknik nuklir menggunakan senyawa bertanda/ radiofarmaka di fasilitas kedokteran nuklir [8]. Pada dasarnya, radiasi mampu merusak sel kanker maupun sel normal, namun tujuan terapi radiasi adalah memaksimalkan dosis radiasi ke sel kanker abnormal dan meminimalkan paparan terhadap sel normal yang berdekatan dengan sel kanker atau yang berada pada jalur radiasi [9]. Radioisotop yang ideal untuk tujuan deteksi dan terapi kanker yaitu radioisotop pemancar radiasi gamma, alfa atau beta, salah satunya adalah adalah iodium-131 (131)). ${ }^{131}$ merupakan radioisotop pemancar gamma dengan energi $364 \mathrm{keV}$ (82\%) sekaligus pemancar beta dengan energi maksimal $606 \mathrm{keV}$ (89\%) [10], serta mempunyai waktu paruh 8 hari. Radioisotop pemancar gamma cocok untuk tujuan deteksi, sedangkan radioisotop pemancar beta memiliki kemampuan merusak sel serta diharapkan terdistribusi lama dalam darah dan jaringan sehingga cocok untuk tujuan terapi kanker. Penggunaan senyawa yang memiliki aktivitas antikanker untuk ditandai dengan ${ }^{131}$ I dimaksudkan agar terapi kanker menghasilkan efek yang maksimal.

Senyawa golongan flavonoid merupakan metabolit sekunder yang mempunyai berbagai aktivitas, diantaranya dapat berperan sebagai antikanker dan antioksidan. Salah satu senyawa flavonoid yang memiliki aktivitas antioksidan tinggi adalah kuersetin [11]. Hasil kajian hubungan kuantitatif antara stuktur kimia dengan aktivitas antiradikal dari senyawa kuersetin menggunakan teknik analisis Free-Wilson menunjukkan persen aktivitas antioksidan kuersetin sebesar 88,775\% [12]. Dari kajian pustaka [13] disebutkan bahwa senyawa yang aktif sebagai antioksidan adalah senyawa yang berpotensi tinggi sebagai kandidat antikanker. Quercetin menunjukkan efek proapoptosis langsung pada sel tumor dan karenanya dapat menghambat perkembangan berbagai kanker manusia [14] dengan adanya ikatan rangkap diantara $\mathrm{C} 2$ dan $\mathrm{C} 3$, serta gugus hidroksil pada posisi C3 yang berperan dalam menghambat proses oksidasi. Aktivitas antiradikal pada kuersetin dipengaruhi juga oleh adanya gugus hidroksil yang terikat pada $\mathrm{C}^{\prime}$ '. Efektivitas kuersetin dalam menangkap radikal bebas meningkat dengan adanya gugus orto-hidroksi pada cincin B [15]. Struktur kimia kuersetin dapat dilihat pada Gambar 1. 
<smiles>O=c1c(O)c(-c2ccc(O)c(O)c2)oc2cc(O)cc(O)c12</smiles>

Gambar 1. Struktur kimia kuersetin

Dalam penelitian ini dilakukan pembuatan senyawa kuersetin bertanda lodium-131. Penelitian ini pertama kali diteliti oleh Maria Graciela Barolli tahun 1997, dengan hasil kemurnian radiofarmaka 99\% [16]. Pada tahun 2015 telah dilakukan penelitian pendahuluan oleh Pusat Sains dan Teknologi Nuklir Terapan (PSTNT), Badan Tenaga Nuklir Nasional (BATAN) mengenai pemilihan metode yang cocok untuk pembuatan senyawa bertanda ${ }^{131}$ I-kuersetin, serta karakterisasi senyawa lodokuersetin nonradioaktif yang telah terbentuk [17]. Dari reaksi iodinasi, telah dapat diidentifikasi bahwa reaksi tersebut menghasilkan senyawa 5',6,8-Natrium Triiodokuersetin yang berbeda dengan penelitian yang telah dilakukan sebelumnya [16].

Sebagai sediaan senyawa bertanda baru, sifat fisik maupun kimia dari senyawa terbentuk harus diketahui. Oleh karena itu pada penelitian ini dilakukan pengujian karakterisasi fisikokimia meliputi: penandaan senyawa kuersetin dengan radioisotop ${ }^{131}$, penentuan kemurnian radiokimia ${ }^{131}$ |-kuersetin, penentuan kemurnian radiokimia pada variasi waktu inkubasi dan volume, variasi waktu penyimpanan, stabilitas dalam dapar atau $\mathrm{NaCl}$, stabilitas dalam plasma darah, penentuan muatan listrik, penentuan lipofilisitas dan penentuan ikatan dengan protein plasma.

\section{METODOLOGI}

\section{Alat dan bahan}

Alat-alat yang digunakan untuk mendukung penelitian ini antara lain Single Channel Analyzer (SCA) dengan detektor Nal(TI) (ORTEC@, model 4890), satu set alat kromatografi, dose calibrator (Victoreen $®)$, shaker

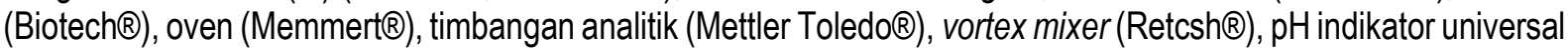
(E. Merck®), syringe (Terumo®), mikropipet berbagai ukuran, tip, vial $10 \mathrm{~mL}$, microtube $2 \mathrm{~mL}$, corong pisah, kontainer timbal penahan radiasi, alat elektroforesis dan alat-alat gelas lainnya.

Bahan-bahan yang digunakan dalam penelitian ini antara lain kuersetin hidrat (Sigma Aldrich $囚$ ), natrium iodida-131 (Na-131I) (BATAN), kloramin T (Sigma Aldrich®), natrium metabisulfit (E. Merck®), natrium hidroksida (E. Merck®), kloroform p.a (E. Merck®), metanol p.a (E. Merck®), asam klorida (E. Merck®), natrium klorida fisiologis 0,9\% (IPHA Laboratories $®$ ), TLC silica gel $\mathrm{F}_{254}$ Aluminum Plate (E. Merck®), aquabides steril (IPHA Laboratories $\left.{ }^{\circledR}\right)$, n-oktanol (TCl), dapar fosfat $0,2 \mathrm{M}$ dan $0,1 \mathrm{M} \mathrm{pH} 7,4$, plasma darah.

\section{Penandaan Kuersetin dengan lodium-131 (131)}

Penandaan diawali dengan, memasukkan larutan kuersetin, kloramin $\mathrm{T}, \mathrm{NaCl}$ fisiologis $0,9 \%$ ke dalam microtube dan dikocok hingga homogen. Setelah itu, ditambahkan iodium-131 dan di cek pH. Campuran kemudian diaduk menggunakan pengocok vortex selama 30 menit pada suhu kamar. Setelah itu, ke dalam sediaan ditambahkan larutan natrium metabisulfit $\left(\mathrm{Na}_{2} \mathrm{~S}_{2} \mathrm{O}_{5}\right)$ dan di cek pH serta radioaktivitasnya dengan menggunakan dose calibrator. Larutan kemudian di pindahkan ke dalam corong pisah untuk dilakukan ekstraksi cair-cair dengan menggunakan kloroform sebanyak $3 \times 1$. Setelah itu kedua fase dipisahkan dan masing-masing fase diukur aktivitas radiokimia akhir. Pengujian kemurnian radiokimia ${ }^{131}$-kuersetin pada fase air dilakukan dengan menggunakan sistem kromatografi lapis tipis dengan fase diam TLC silica gel $\mathrm{F}_{254}$ aluminum plate dan fase gerak metanol p.a. KLT dipotong-potong sepanjang $1 \mathrm{~cm}$ kemudian masing-masing bagian dicacah menggunakan alat pencacah single channel analyzer (SCA) yang dilengkapi detektor Nal(TI). 


\section{Penentuan Kemurnian Radiokimia ${ }^{131} \mid-K u e r s e t i n$}

Kemurnian radiokimia ${ }^{131}$-kuersetin ditentukan dengan metode kromatografi lapis tipis menggunakan TLC silica gel $F_{254}$ Aluminum plate sebagai fase diam serta fase gerak larutan metanol p.a. Penentuan kemurnian radiokimia dilakukan dengan menggunakan pencacah single channel analyzer (SCA). Kemurnian radiokimia ${ }^{131}$ Kuersetin ditentukan pula pada selang waktu $0,15,30$, dan 45 menit.

\section{Pengaruh Volume Akhir terhadap Kemurnian Radiokimia ${ }^{131} \mid$-Kuersetin}

Sediaan ${ }^{131} \mid$-Kuersetin dimasukkan ke dalam 5 buah vial yang masing-masing ditambahkan $\mathrm{NaCl}$ Fisiologis $0,9 \%$ dengan volume yang bervariasi $(1 ; 1,5 ; 3$ dan $5 \mathrm{~mL})$. Campuran dikocok hingga homogen, dan dicatat radioaktivitasnya. Pengujian kemurnian radiokimia dilakukan dengan cara kromatografi lapis tipis.

\section{Pengaruh Penambahan Dapar atau NaCl terhadap Radiofarmaka ${ }^{131}$-Kuersetin}

Pengujian dilakukan terhadap hasil penandaan sediaan radiofarmaka ${ }^{131}$-kuersetin yang ditepatkan

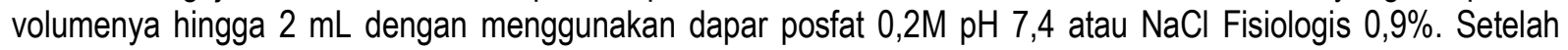
pengenceran, masing-masing di cek pH dan kemurnian radiokimianya pada waktu $0,1,2,3,4,5,24,48$ dan 72 jam setelah penandaan dengan penyimpanan pada suhu kamar

\section{Pengujian Stabilitas ${ }^{131} \mid$-kuersetin dalam Plasma Darah}

Pengujian stabilitas dalam plasma darah dilakukan secara in-vitro menggunakan plasma darah manusia (human plasma). Sebanyak 100-250 $\mu \mathrm{Ci} / 250 \mu \mathrm{L}$ radiofarmaka ${ }^{131}$-kuersetin ditambahkan ke dalam vial yang berisi $500 \mu \mathrm{L}$ plasma darah manusia. Vial divakum secara manual, kemudian dikocok dengan pengaduk vortex. Campuran diinkubasi dalam inkubator pada suhu $37^{\circ} \mathrm{C}$ dan setiap waktu tertentu $(15,30,45$ menit, 1,2 dan 3 jam) ditentukan kemurnian radiokimianya dengan metode kromatografi lapis tipis.

\section{Penentuan Lipofilisitas Radiofarmaka ${ }^{131} \mid$-Kuersetin}

Penentuan lipofilisitas dilakukan dengan memodifikasi metode yang telah diperoleh pada penelitian sebelumnya (Nurlaila, Z dan Eva M.W., 2009). Ke dalam tabung sentrifuga yang berisi $2 \mathrm{~mL}$ oktanol dan $2 \mathrm{~mL} \mathrm{NaCl}$ fisiologis (0,9\%) pH 7,4 dimasukkan 10-50 $\mu \mathrm{L}$ (10-50 $\mu \mathrm{Ci}$ ) sediaan ${ }^{131}$-kuersetin. Campuran dikocok dengan pengaduk vortex selama 1 menit, kemudian disentrifugasi dengan kecepatan 3000 putaran/menit selama 10 menit. Sebanyak 50 - $100 \mu \mathrm{L}$ masing-masing fraksi (oktanol dan $\mathrm{NaCl}$ ) diambil dan dicacah dengan alat pencacah saluran tunggal. Lapisan oktanol dipindahkan ke dalam tabung lain, ditambah larutan $\mathrm{NaCl}$ fisiologis ( $0,9 \%)$ dengan volume yang sama. Percobaan diulangi lagi sampai diperoleh nilai koefisien partisi yang relatif konstan. Perbandingan besarnya cacahan fase oktanol dan fase $\mathrm{NaCl}$ menunjukkan besarnya lipofilisitas, dinyatakan sebagai koefisien partisi sediaan, yang dapat dihitung dengan persamaan berikut:

$$
\text { Lipofilisitas }(P)=\frac{\text { cacahan fase oktanol }}{\text { cacahan fase } \mathrm{NaCl}}
$$

\section{Penentuan Besarnya Ikatan Protein Plasma}

Ke dalam tabung sentrifuga yang berisi $500 \mu \mathrm{L}$ plasma darah manusia ditambahkan 10-50 $\mu \mathrm{Ci} / 50 \mu \mathrm{L}$ radiofarmaka ${ }^{131} \mid$-kuersetin, kemudian dikocok dengan pengaduk vortex selama 1 menit. Campuran diinkubasi pada suhu $37^{\circ} \mathrm{C}$ selama 10 menit, lalu ditambah $1 \mathrm{~mL}$ larutan $\mathrm{NaCl}$ fisiologis (0,9\%) dan $1 \mathrm{~mL}$ larutan asam trikoloro asetat (TCA) $5 \%$, dikocok lagi dengan pengaduk vortex. Selanjutnya campuran disentrifugasi pada $300 \mathrm{rpm}$ selama 15 menit. Setelah itu supernatan dan endapan dipisahkan, masing-masing fraksi dicacah dengan alat pencacah saluran tunggal. Besarnya ikatan dengan protein plasma dapat dihitung menggunakan persamaan berikut:

$$
\text { Ikatan Protein Plasma }(\%)=\frac{\text { cacahan endapan }}{\text { cacahan endapan }+ \text { cacahan supernatan }} \times 100
$$




\section{Penentuan Muatan Listrik Radiofarmaka ${ }^{131} \mid-K u e r s e t i n$}

Muatan listrik radiofarmaka ${ }^{131}$ |-kuersetin ditentukan dengan metode elektroforesis selulosa asetat. Fase diam yang digunakan adalah selulosa asetat dengan ukuran $13 \mathrm{~cm} \times 0,5 \mathrm{~cm}$ yang telah diberi tanda pada setiap sentimeternya dengan angka-angka dari nol pada bagian tengah sampai dengan negatif $13(-13)$ pada salah satu sisi, dan positif $13(+13)$ pada sisi yang lainnya. Larutan dapar fosfat $0,1 \mathrm{M} \mathrm{pH} \mathrm{7,4} \mathrm{dimasukkan} \mathrm{ke} \mathrm{dalam} \mathrm{alat}$ elektroforesis dan dimasukkan kertas saring sebagai alas. Sebelum dilakukan pengujian, strip selulosa asetat terlebih dahulu di rendam dengan larutan dapar fosfat $0,1 \mathrm{M} \mathrm{pH} \mathrm{7,4} \mathrm{selama} 15$ menit. Potongan strip ini dipasangkan pada alat elektroforesis dengan posisi titik nol berada di tengah dan sisi negatif diletakkan pada katoda, sedangkan sisi positif pada anoda. Pada titik nol diteteskan radiofarmaka ${ }^{131} \mid$-kuersetin yang akan dianalisis. Kemudian alat elektroforesis ditutup, dan arus listrik dialirkan dengan perbedaan tegangan antara 2 kutub sebesar 200 Volt selama 1 jam. Setelah selesai kertas diangkat, dikeringkan, dipotong-potong tiap $0,5 \mathrm{~cm}$ dan tiap potongan dicacah dengan alat pencacah saluran tunggal. Dari hasil ini dapat diketahui muatan listrik radiofarmaka ${ }^{131} \mid$-kuersetin.

\section{HASIL DAN PEMBAHASAN}

Parameter fisikokimia yang dilakukan dalam penelitian ini meliputi inkubasi sediaan, pengaruh penambahan larutan pengencer (dapar fosfat dan $\mathrm{NaCl}$ fisiologis), stabilitas selama penyimpanan dan dalam plasma protein, lipofilisitas, ikatan dengan protein plasma, dan muatan listrik senyawa ${ }^{131} \mid$-kuersetin. Berikut adalah hasil pengujian karakteristik fisikokimia yang didapatkan.

Pengujian variasi waktu inkubasi dilakukan untuk memastikan waktu inkubasi optimal dengan mengamati dan menentukan kemurnian radiokimia ${ }^{131}$-kuersetin dalam waktu 5, 15, 30 dan 45 menit. Hasil yang diperoleh diperlihatkan pada Gambar 2. Berdasarkan tiga kali pengulangan didapatkan nilai KRK pada 5, 15, 30 dan 45 menit masing-masing sebesar $99,45 \pm 0,66 \% ; 99,13 \pm 0,16 \% ; 97,54 \pm 1,35 \%$; dan $97,81 \pm 1,59 \%$. Dapat disimpulkan bahwa pada waktu inkubasi selama $5,15,30$ dan 45 menit diperoleh kemurnian radiokimia yang cukup tinggi dan memenuhi syarat British Pharmacopeia dan United State of Pharmacopeia yaitu >90 serta Farmakope Indonesia [22]. Hasil penandaan dengan KRK >90\% sudah didapatkan mulai menit ke 5.

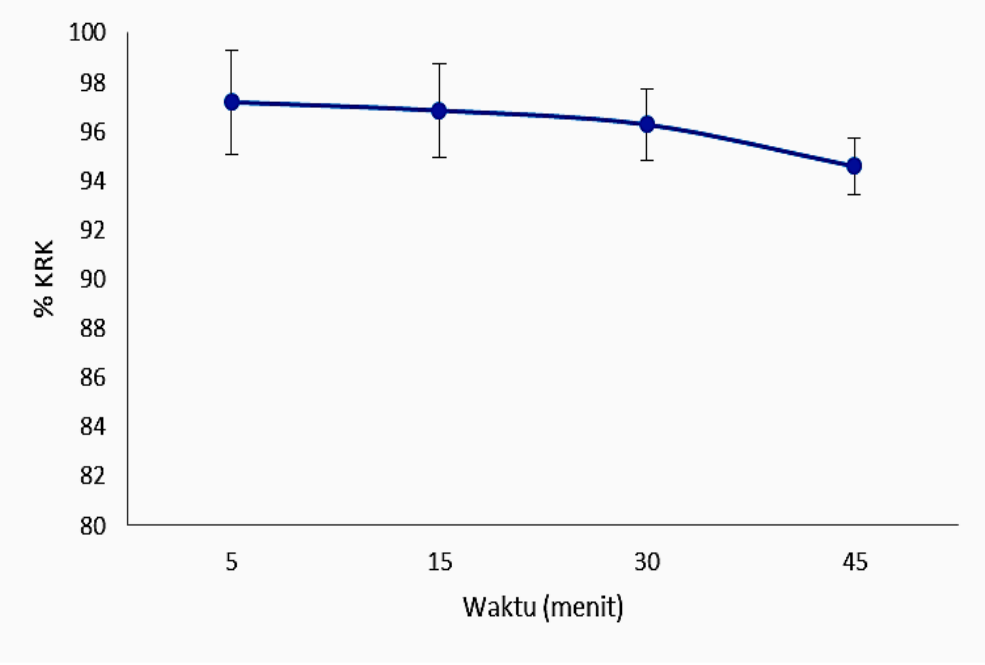

Gambar 2. Pengaruh waktu inkubasi terhadap KRK ${ }^{131}$-kuersetin

Karakterisasi fisikokimia yang selanjutnya diteliti adalah pengaruh variasi volume akhir terhadap radiofarmaka ${ }^{131} \mid$-Kuersetin. Pengenceran dilakukan dengan penambahan $\mathrm{NaCl}$ fisiologis $0,9 \%$. Penentuan kemurnian radiokimia dilakukan dengan menggunakan alat Single Channel Analyzer (SCA). Pengujian ini dilakukan dengan memvariasikan volume akhir sediaan menjadi masing-masing 1; 1,5; 3 dan $5 \mathrm{~mL}$. Aktivitas dari 
sediaan masing-masing sebesar $0,150 \mathrm{mCi}$ setelah ditambahkan $\mathrm{NaCl}$ fisiologis $0,9 \%$. Pengujian ini dilakukan sebanyak tiga kali pengulangan. Hasil pengujian dapat dilihat pada Gambar 3.

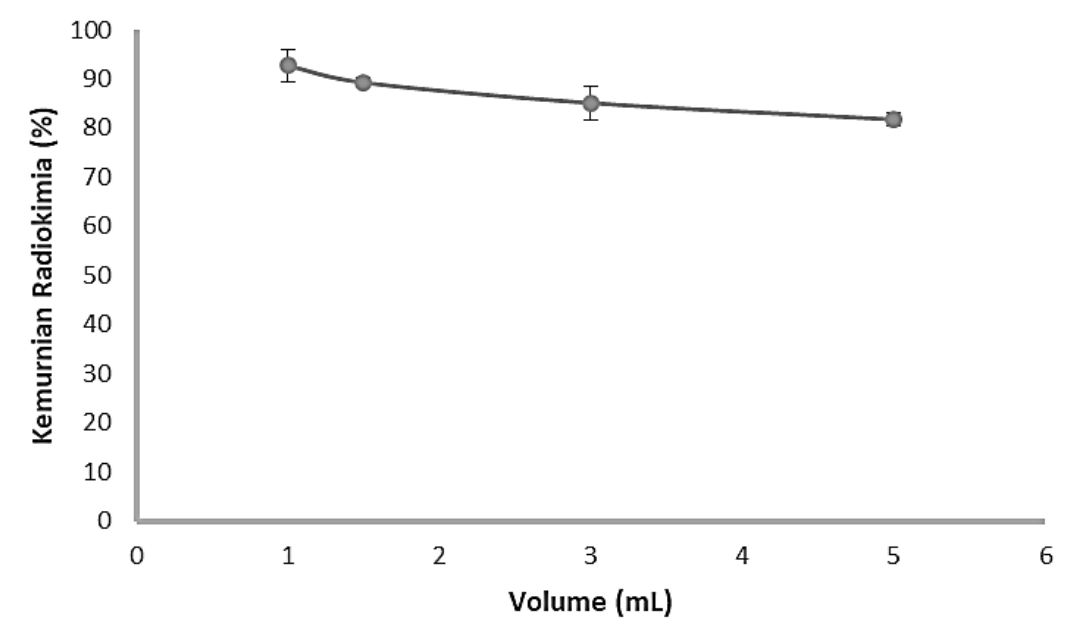

Gambar 3. Pengaruh volume akhir terhadap KRK ${ }^{131} \mid$-kuersetin

Hasil yang diperoleh dengan menggunakan alat Single Channel Analyzer (SCA) menunjukkan penurunan kemurniaan radiokimia pada volume 1,$5 ; 3$ dan $5 \mathrm{~mL}$ yaitu masing-masing sebesar $89,25 \pm 0,90 \%, 85,11 \pm 3,36 \%$ dan $81,74 \pm 1,28 \%$. Pada volume $1 \mathrm{~mL}$ diperoleh KRK sebesar $92,71 \pm 3,27 \%$. Hal ini kemungkinan terjadi karena pengaruh dari pengenceran ${ }^{131}$-Kuersetin membuat volume dari sediaan menjadi lebih besar/encer sehingga reaksi berjalan dengan lambat dan membutuhkan waktu yang lebih lama untuk menghasilkan kemurnian radiokimia yang optimum $>90 \%$. Dapat disimpulkan bahwa pada variasi volume radiofarmaka ${ }^{131} \mid$-Kuersetin, jumlah larutan sebanyak $1 \mathrm{~mL}$ memiliki kemurnian radiokimia yang optimal.

Setelah diketahui waktu inkubasi optimal, dilakukan juga pengaruh penambahan pelarut untuk mengencerkan sediaan ${ }^{131}$-kuersetin. Pada saat melakukan reaksi penandaan, $\mathrm{pH}$ awal sediaan adalah 11 , sedangkan pada penelitian yang dilakukan oleh Xinghua Qie et.al [19], pH penendaan berada pada pH netral. Hal ini dikarena adanya perbedaan pelarut yang digunakan dalam penandaan serta adanya penambahan asam asetat yang digunakan dalam penelitian tersebut. Nilai pH yang didapat dalam penelitian ini cukup tinggi, sehingga tidak memenuhi persyaratan sediaan injeksi. Oleh karena itu dilakukan pengenceran sediaan ${ }^{131 \mid}$-kuersetin dengan menambahkan $\mathrm{NaCl}$ fisiologis atau larutan dapat fosfat $0,2 \mathrm{M} \mathrm{pH} 7,4$. Setelah pengenceran, $\mathrm{pH}$ sediaan berubah menjadi 10 untuk penambahan $\mathrm{NaCl}$ fisiologis dan $\mathrm{pH}$ 7,5 untuk penambahan larutan dapar fosfat.

Adanya penurunan $\mathrm{pH}$ pada penambahan larutan dapar fosfat dikhawatirkan dapat mempengaruhi nilai kemurnian radiokimia ${ }^{131}$-kuersetin. Oleh karena itu dilakukan penentuan kemurnian radiokimia ${ }^{131}$-kuersetin dengan penambahan kedua larutan tersebut. Hasil pengaruh penambahan dapar atau $\mathrm{NaCl}$ fisiologis dapat dilihat pada Tabel 1.

Tabel 1. Pengaruh Penambahan Dapar atau $\mathrm{NaCl}$ fisiologis terhadap KRK

\begin{tabular}{|c|c|c|}
\hline \multirow{2}{*}{ RERATA } & \multicolumn{2}{|c|}{ \%KRK } \\
\hline & Dapar & $\mathrm{NaCl}$ \\
\hline${ }^{131}$ Iodium & \multicolumn{2}{|c|}{$100,00 \pm 0,00$} \\
\hline 131|-kuersetin & $98,06 \pm 1,18$ & $96,54 \pm 1,46$ \\
\hline
\end{tabular}

Pengujian stabilitas ${ }^{131} \mid$-kuersetin selama penyimpanan dilakukan untuk memberikan informasi kepada pengguna berapa lama sediaan ini dapat digunakan setelah diformulasi tanpa terjadi reaksi yang tidak diinginkan dan tetap terjamin kualitasnya. 
Pengujian stabilitas sediaan ${ }^{131} \mid$-kuersetin yang ditampilkan pada Gambar 4. bertujuan untuk menentukan waktu kadaluwarsa (shelf life). Dari hasil yang diperoleh pada 0 jam sampai dengan 72 jam masih menunjukkan tingkat kemurnian diatas $90 \%$, artinya sediaan ini masih memenuhi persyaratan sebagai sediaan radiofarmasi.

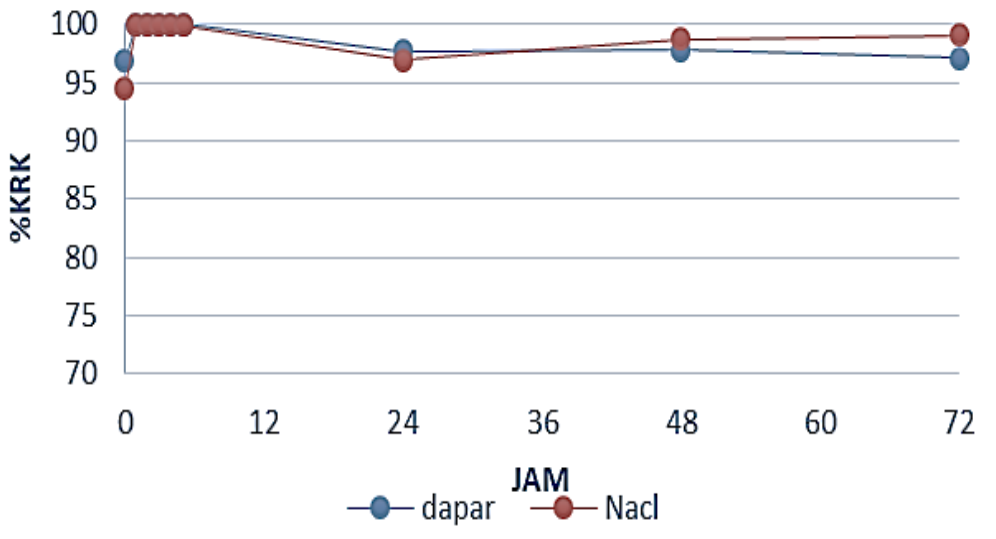

Gambar 4. Pengaruh penambahan dapar atau $\mathrm{NaCl}$ terhadap stabilitas ${ }^{131 \mid}$-kuersetin.

Pada pengujian pengaruh penambahan dapar atau $\mathrm{NaCl}$ terhadap stabilitas radiofarmaka ${ }^{131} \mid-k u e r s e t i n$, diperlihatkan bahwa dengan penambahan $\mathrm{NaCl}$, maka ${ }^{131}$-kuersetin memiliki kemurnian radiokimia yang lebih tinggi yaitu $99,11 \pm 0,34 \%$ dibandingkan dengan penambahan dapar yaitu $97,12 \pm 2,50 \%$. Hal ini disebabkan $\mathrm{pH}$ pada penambahan $\mathrm{NaCl}$ tidak terlalu banyak perubahan yaitu dari pH awal 11 menjadi $\mathrm{pH}$ 10, sedangkan pada penambahan dapar terjadi perubahan $\mathrm{pH}$ yang signifikan yaitu dari $\mathrm{pH}$ awal 11 menjadi $\mathrm{pH}$ 7,4.

Berdasarkan hasil tersebut, karena pada penambahan/pengenceran menggunakan larutan $\mathrm{NaCl}$ fisiologis diperoleh $\mathrm{pH}$ akhir yang tinggi (10), maka untuk selanjutnya, pengenceran sediaan ${ }^{13 I} \mid$-kuersetin dilakukan dengan menggunakan larutan dapar fosfat 0,2 N pH 7,4 yang masih menunjukkan nilai kemurnian radiokimia yang cukup tinggi (>95\%), serta $\mathrm{pH}$ yang cukup netral mendekati nilai pH cairan tubuh.

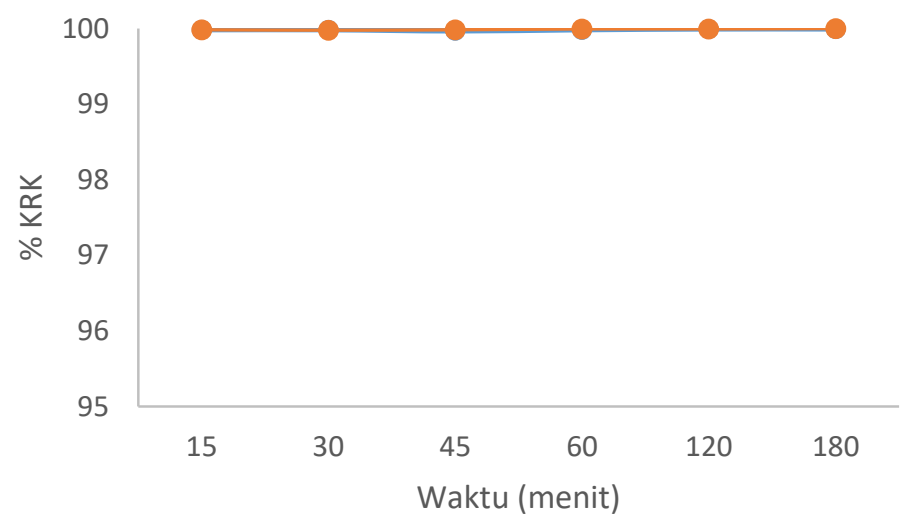

Gambar 5. Grafik stabilitas ${ }^{131} \mid$-kuersetin dalam plasma darah

Stabilitas radiofarmaka ${ }^{131} \mid$-Kuersetin (Dapar \& $\mathrm{NaCl}$ ) dalam plasma atau cairan biologis juga perlu diketahui mengingat bahwa untuk tujuan diagnosis dengan metode pencitraan umumnya radiofarmaka tersebut akan diberikan secara intra vena, sehingga kestabilan dalam plasma darah perlu dipelajari. Pengujian stabilitas radiofarmaka ${ }^{131}$-Kuersetin (Dapar dan $\mathrm{NaCl}$ ) dalam plasma menunjukkan bahwa pada penyimpanan 3 jam masih didapatkan kemurnian radiokimia yang memenuhi syarat $>90 \%$ (Gambar 5.).

Parameter karakteristik fisikokimia lainnya yang dilakukan dalam penelitian ini yaitu nilai lipofilisitas dari ${ }^{131} \mid$-Kuersetin yang disimpan dalam larutan dapar dan $\mathrm{NaCl}$. Penentuan nilai koefisien partisi ( $\left.\mathrm{P}_{\text {oclair }}\right)$ suatu radiofarmaka sangat penting untuk mengetahui cara kerja atau akumulasi radiofarmaka apabila telah dimasukkan ke dalam tubuh [24]. Semakin tinggi nilai koefisien partisi, maka senyawa tersebut semakin mudah larut dalam 
lemak (lipofil) dan akan mudah menembus lapisan lipid [25]. Namun sebaliknya, semakin rendah nilai koefisien partisi, maka senyawa tersebut semakin larut dalam air (hidrofil) dan akan mudah diekskresikan melalui ginjal. Fase nonpolar yang digunakan dalam hal ini yaitu n-Oktanol.

Berdasarkan tiga kali pengulangan, sediaan ${ }^{131} \mid-K u e r s e t i n$ (Dapar) didapatkan nilai lipofilisitas atau Log $(P)=-2,71$, sedangkan pada sediaan ${ }^{131}$-Kuersetin $(\mathrm{NaCl})$ diperoleh nilai lipofilisitas atau $\mathrm{Log}(\mathrm{P})=-2,22$ (Tabel 2). Hal ini menunjukkan bahwa sediaan ${ }^{131} \mid-K u e r s e t i n$ dengan penambahan dapar dan $\mathrm{NaCl}$ bersifat hidrofil dan akan mudah diekskresikan melalui ginjal [19].

Parameter selanjutnya yang dilakukan adalah penentuan ikatan antara sediaan ${ }^{131}$ |-Kuersetin dalam dapar dan $\mathrm{NaCl}$ dengan protein plasma darah. Besarnya ikatan radiofarmaka dengan protein plasma menunjukkan berapa banyak sediaan tersebut terikat dalam protein di dalam darah dan berapa besarnya radiofarmaka yang tidak terikat oleh protein plasma.

Dari hasil yang diperoleh, cacahan radioaktivitas pada fase endapan (TCA 5\%) lebih kecil dibandingkan supernatan ( $\mathrm{NaCl}$ Fisiologis $0,9 \%$ ). Hal Ini menunjukkan terdapat ikatan antara protein dengan sediaan radiofarmaka ${ }^{131}$-Kuersetin (dapar) dan ${ }^{131} \mid$-Kuersetin $(\mathrm{NaCl})$. Besarnya ikatan ini akan mempengaruhi lamanya waktu paruh biologis dari radiofarmaka.

Tabel 2. Karakteristik Radiofarmaka ${ }^{131} \mid-k u e r s e t i n(d a p a r)$ dan ${ }^{131} \mid-k u e r s e t i n(\mathrm{NaCl})$

\begin{tabular}{cccc}
\hline No & Jenis Pengujian & Dapar & NaCl \\
\hline 1 & Lipofilisitas $(P)$ & $-2,71$ & $-2,22$ \\
2 & Ikatan Protein Plasma & $32,94 \pm 1,46 \%$ & $34,64 \pm 4,37 \%$ \\
\hline
\end{tabular}

Karakteristik fisiko-kimia lainnya yang perlu ditentukan dalam penelitian ini adalah muatan listrik dari sediaan radiofarmaka. Hal ini perlu dilakukan karena interaksi antara molekul radiofarmaka dengan permukaan membran sel tubuh tergantung pada sifat muatan listrik dari molekul dan permeabilitas membran [26].

Pada penggunaan elektroforesis selulosa asetat, Kontrol ${ }^{131}$ | bergerak ke arah anoda yang menunjukkan bahwa ${ }^{131} \mid$ ini memiliki muatan negatif, dan untuk senyawa ${ }^{131}$-Kuersetin juga bergerak ke arah anoda yang berarti bermuatan negatif. Hasil pengujian dapat dilihat pada Gambar 6 di bawah ini.

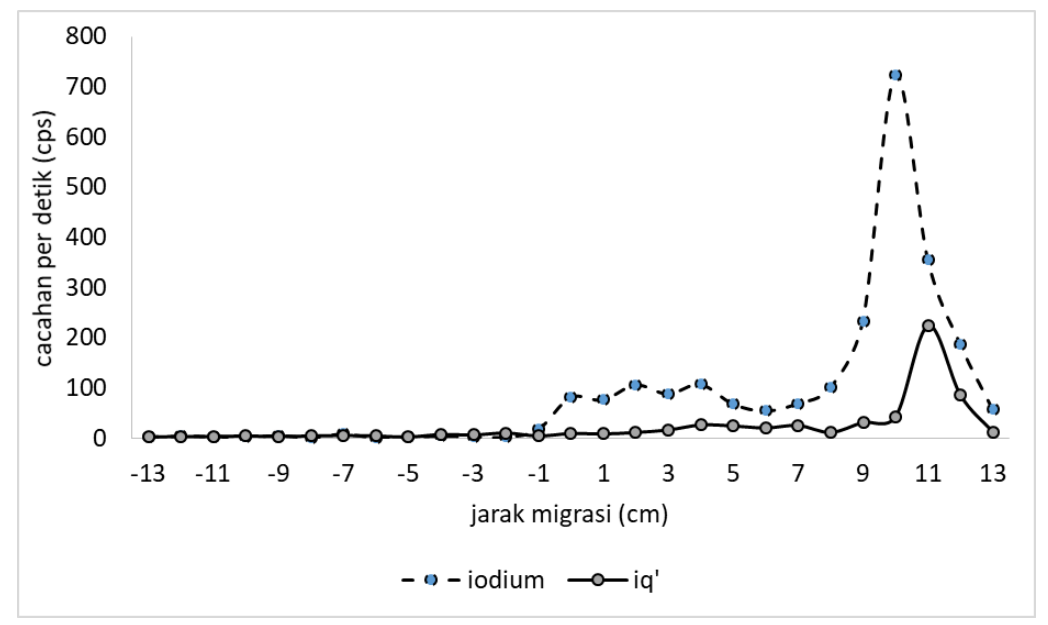

Gambar 6. Hasil Elektroforesis ${ }^{131} \mid$-kuersetin.

\section{KESIMPULAN}

Kesimpulan dari penelitian ini bahwa sediaan sudah didapatkan melalui inkubasi selama 5 menit, volume total $1 \mathrm{~mL}$ dengan kemurnian radiokimia sebesar $99,45 \pm 0,66 \%$. Sediaan ${ }^{131}$ I-Kuersetin masih menunjukkan tingkat kemurnian di atas $90 \%$ setelah disimpan selama 72 jam pada suhu ruang $\left( \pm 25^{\circ} \mathrm{C}\right)$. Karakteristik sediaan 
${ }^{131} \mid$-kuersetin pada pengenceran menggunakan larutan $\mathrm{NaCl}$ fisiologis yaitu $\mathrm{pH} 10$, kemurnian radiokimia sebesar $96,54 \pm 1,46 \%$, nilai lipofilisitas ( $\log P)=-2,22$ dan nilai ikatan pada protein plasma sebesar $34,64 \pm 4,37$. Sedangkan karakteristik sediaan ${ }^{131}$-kuersetin pada pengenceran menggunakan dapar fosfat $0,2 \mathrm{~N} \mathrm{pH} \mathrm{7,4}$ yaitu pH 7,5 dengan kemurnian radiokimia sebesar $98,06 \pm 1,18 \%, \log (P)=-2,71$ dan nilai ikatan sediaan dengan protein plasma sebesar $32,94 \pm 1,46 \%$. Hasil penentuan muatan listrik sediaan ${ }^{131} \mid$-Kuersetin memiliki muatan negatif dengan menggunakan metode elektroforesis kertas.

\section{UCAPAN TERIMA KASIH}

Ucapan terimakasih disampaikan kepada PSTNT-BATAN yang telah mendanai penelitian ini melalui DIPA-BATAN serta menyediakan fasilitas dan sarana penelitian. Penulis juga mengucapkan terimakasih kepada (alm.) Bapak Nana yang telah membantu penyediaan iodium-131 dan RS. Hasan Sadikin serta semua pihak yang telah membantu keberhasilan dan kelancaran kegiatan penelitian.

\section{DAFTAR PUSTAKA}

[1]. Kementerian Kesehatan Republik Indonesia, "Situasi penyakit kanker." Pusat data dan informasi Kementerian Kesehatan RI, Jakarta, pp. 1-8, 2015.

[2]. WHO, "Latest global cancer data," no. September, pp. 13-15, 2018.

[3]. M. Wahidin, "Deteksi dini kanker leher rahim dan kanker payudara di Indonesia 2007 - 2014," Bul. jendela data dan infoemasi Kesehat., vol. semester 1, no. 2, pp. 12-15, 2015.

[4]. G. A. R. Dyanti and N. L. P. Suariyani, "FAKTOR-FAKTOR KETERLAMBATAN PENDERITA KANKER PAYUDARA DALAM MELAKUKAN PEMERIKSAAN AWAL KE PELAYANAN KESEHATAN," J. Kesehat. Masy., vol. 11, no. 2, pp. 96-104, 2016.

[5]. C. A. Wijaya and M. Muchtaridi, "Pengobatan Kanker Melalui Metode Gen Terapi," Fak. Farm. Univ. Padjadjaran, Sumedang, Jawa Barat, Indones., vol. 15, pp. 53-68, 2017.

[6]. H. Sabrida, "Peranan Deteksi Dini Kanker untuk Menurunkan Penyakit Kanker 'STADIUM LANJUT,'” Bul. JENDELA DATA Inf. Kesehat., vol. semester 1, no. 3, pp. 16-24, 2015.

[7]. T. Kanker-Serviks, "PANDUAN LENGKAP MENGHADAPI BAHAYA KANKER SERVIKS," 2010, pp. 1-35.

[8]. N. K. Oekar and E. Al, "Karakteristik Fisiko-Kimia dan Bioafinitas Tc-Glukosa-6-Fosfat Terhadap Jaringan Tumor Dalam Hewan Model," J. Sains dan Teknol. Nukl. Indones., vol. 15, no. 1, pp. 19-34, 2014.

[9]. N. Fitriatuzzakiyyah, R. K. Sinuraya, I. M. Puspitasari, D. Farmakologi, and F. Farmasi, "Terapi Kanker dengan Radiasi : Konsep Dasar Radioterapi dan Perkembangannya di Indonesia," J. Farm. Klin. Indones., vol. 6, no. 4, pp. 311-320, 2017.

[10]. T. Alexander, "I-131 fact sheet," Facilities and operations Occupational safety and environmental health university og Michigan, Michigan, pp. 1-5, 2018.

[11]. N. Russo, M. Toscano, and N. Uccella, "Semiempirical molecular modeling into quercetin reactive site: Structural, conformational, and electronic features," J. Agric. Food Chem., vol. 48, no. 8, pp. 3232-3237, 2000.

[12]. Iqmal Tahir; Karna Wijaya; Dinni W., "Hubungan Kuantitatif Struktur- Aktivitas Antiradikal Senyawa Turunan Flavon / Flavonol Berdasarkan Pendekatan Free-Wilson," Pros. Semin. Nas. Kim. Fis. III, no. Maret, 2003.

[13]. Handayani, S., Arianingrum, R., dan Haryadi, W., "Antioxidants and Anticancer Activity of Benzalacetone Derivates," Sci. Technol. Res. J. (Jurnal Penelit. Saintek) (In Indones., vol. 18, pp. 71-83, 2013.

[14]. A. Rauf, M. Imran, I. Ali, and K. Mujeeb, "Anticancer Potential of Quercetin : A Comprehensive Review Anticancer potential of quercetin : A comprehensive review," no. July, 2018.

[15]. R. Ravichandran, M. Rajendran, and D. Devapiriam, "Structural characterization and physicochemical properties of quercetin-Pb complex," J. Coord. Chem., vol. 67, no. 8, pp. 1449-1462, 2014. 
[16]. M. G. Barolli and A. B. Pomilio, "Synthesis of [131-I]-lodinated Quercetin," J. Label. Compd. Radiopharm., vol. XXXIX, no. 11, pp. 927-933, 1997.

[17]. M. E. Sriyani, D. A. Utami, E. M. Widyasari, and M. Marzuki, "Iodination Method of Quercetin for Synthesis of Anticancer Labelled Compound," Procedia Chem., vol. 16, pp. 245-250, 2015.

[18]. M. E. Sriyani et al., "Synthesis of 131 I Labeled Quercetin through Oxidation Method Using Chloramine-T for Cancer Radiopharmaceuticals," Indones. J. Chem., vol. 19, no. 4, pp. 841-848, 2019.

[19]. Q. Xie et al., "Preparation and evaluation of 131l-quercetin as a novel radiotherapy agent against dedifferentiated thyroid cancer," J. Radioanal. Nucl. Chem., vol. 311, no. 3, pp. 1697-1708, 2017.

[20]. B.-N. Park et al., "Synthesis of lodine-123 Labeled Quercetin and Cathechin as Radical Seeking Agents," J. Label. Compd. Radiopharm., vol. 44, Supp.1, pp. 957-958, 2001.

[21]. E. M. Widyasari, T. H. a Wibawa, W. Nuraeni, and Misyetti, "Karakteristik Fisikokimia Kit Kering Kanamycin," J. Sains dan Teknol. Nukl. Indones., vol. 43, no. August 2013, pp. 117-126, 2013.

[22]. Kementerian Kesehatan Republik Indonesia, Farmakope Indonesia, V. Jakarta: Dirjen Bina Kefarmasian dan Alat Kesehatan, 2014.

[23]. N. Zainudin, M. E. Sriyani, and E. M. Widyasari, "Pengembangan Formulasi Radiofarmaka siprofloksasin dalam wadah Tunggal," Maj. Farm. Indones., vol. 21, no. 2, pp. 139-149, 2010.

[24]. C. Vraka and M. Mitterhauser, "Reconsider logP!," Nucl. Med. Biol., vol. 54, p. 42, 2017.

[25]. S. Z. Lever, K. H. Fan, and J. R. Lever, "Tactics for preclinical validation of receptor-binding radiotracers," Nucl. Med. Biol., vol. 44, pp. 4-30, 2017.

[26]. G. B. Saha, fundamentals of nuclear pharmacy, Sixth. Cleveland: Springer, 2010. 